\title{
Livelihood vulnerability to shocks, behaviour and investment in education
}

Citation for published version (APA):

Adem, J. M. (2019). Livelihood vulnerability to shocks, behaviour and investment in education: Essays in behavioural development economics. [Doctoral Thesis, Maastricht University]. ProefschriftMaken Maastricht. https://doi.org/10.26481/dis.20191216ja

Document status and date:

Published: 01/01/2019

DOI:

10.26481/dis.20191216ja

Document Version:

Publisher's PDF, also known as Version of record

\section{Please check the document version of this publication:}

- A submitted manuscript is the version of the article upon submission and before peer-review. There can be important differences between the submitted version and the official published version of record.

People interested in the research are advised to contact the author for the final version of the publication, or visit the DOI to the publisher's website.

- The final author version and the galley proof are versions of the publication after peer review.

- The final published version features the final layout of the paper including the volume, issue and page numbers.

Link to publication

\footnotetext{
General rights rights.

- You may freely distribute the URL identifying the publication in the public portal. please follow below link for the End User Agreement:

www.umlib.nl/taverne-license

Take down policy

If you believe that this document breaches copyright please contact us at:

repository@maastrichtuniversity.nl

providing details and we will investigate your claim.
}

Copyright and moral rights for the publications made accessible in the public portal are retained by the authors and/or other copyright owners and it is a condition of accessing publications that users recognise and abide by the legal requirements associated with these

- Users may download and print one copy of any publication from the public portal for the purpose of private study or research.

- You may not further distribute the material or use it for any profit-making activity or commercial gain

If the publication is distributed under the terms of Article $25 \mathrm{fa}$ of the Dutch Copyright Act, indicated by the "Taverne" license above, 
The dissertation provides theoretical analysis and empirical evidence on the psychological and social drivers of economic behaviour and decision making. The contents of the dissertation are organized in seven chapters, starting with a general introduction.

Chapter 2 provides ambition-based model of reference-dependent preferences for decision-making under risk. The proposed model draws on the concepts of expected utility theory (EUT), prospect theory (PT) and regret theory (RT). The main innovation of the model is that it provides a systematic mechanism of determining objectively measurable reference points for loss and gain. The model accounts for the two important considerations in decision making under risk: security and potential for growth. The model is built based on the idea that people regret not only their failure to secure a certain/guaranteed moderate outcome in a choice set but also their reluctance to take an opportunity of increasing their welfare. It suggests that the maxmin outcome of a choice set, the certain maximum possible outcome, has the necessary attributes to set a reference point for loss. The model can be applied to any decision making under risk and uncertainty with any number of alternatives and outcomes. It also allows heterogeneity of risk-preferences and complete interpretation of observed behaviour.

Chapter 3 extends the model proposed in chapter 2: it provides a theoretical explanation of why risk-preferences might be heterogeneous. The theoretical framework suggested in chapter 3 specifically shows how inequality and social comparison influence individual risk-attitude. The result from this chapter indicates that higher inequality in economic status relative to the inequality of initial endowments renders the poor more risk takers or less risk-averse. Conversely, higher inequality of economic status relative to inequality of opportunities makes the rich less risk takers or more risk-averse. The psychological force that transforms inequalities into risk preferences is the constellation of individual aspirations and frustrations of an individual to achieve economic performance parity with her social reference group. The model also shows that individual risk preference is influenced more by those people the individual frequently interacts with or by those whom the individual has more information about their endowments than by distant networks. The results imply that equalization of opportunities and increasing the exposure of the poor to information about successful role models could increase risk-taking by the poor. It further shows that income and wealth redistribution can increase risk-taking by the poor.

The fourth chapter provides empirical evidence on the sources of preference heterogeneity in a low-income country setting. The analysis in this chapter uses data obtained through an artefactual behavioural experiment conducted in Ethiopia. The results show that livelihood vulnerability to shock increases risk aversion or lossaversion. It is also found that women tend to be more loss-averse/risk-averse. The 
findings also shed light on the long-term effects of emotions, and the long-standing academic question of whether preferences are stable or would endure lasting changes (shift) in response to changes in the socioeconomic environment.

Chapter 5 applies behavioural insights to provide theoretical and empirical explanations of why cash transfer or similar programmes fail to bring about significant improvement of long-term development outcomes. The results indicate that inseparability of investment and consumption in developing countries coupled with vulnerability of consumption/livelihood to shock discourages household investment. The analysis mainly focuses on household investment in child scholastic learning-enhancing homebased resources. It further demonstrates that designing intervention programmes as cost-sharing schemes is a more effective way than lump-sum grant schemes to achieve specific development goals. Drawing on data from artefactual behavioural experiment, the chapter also provides an empirical test of the proposed theoretical framework. The empirical results are consistent with the predictions of the theoretical model.

Chapter 6 empirically investigates the role of parental preferences for inter-child allocation of educational investments. It uses data from behavioural experiment. The results from this chapter show the important roles played by non-price factors, such as parental aspirations and perceptions for household allocation of resources in child education. The results indicate the possibility of improving scholastic learning outcomes in low income countries through provission of information about the positive performance or qualities of children for parents, and raising parental aspirations.

Finally, chapter 7 concludes the dissertation. It highlights the main findings and contributions of the dissertation. 